\title{
Developing the Structure of a Hardware and Software System for Quantitative Diagnosis of Microhemodynamics
}

\author{
P.V. Luzhnov; T.O. Pika; D.M. Shamaev \\ Biomedical Engineering Department, Bauman Moscow State Technical University \\ Moscow, the Russian Federation
}

\begin{abstract}
Currently, vascular diseases are the leading cause of disability all over the world. Recent publications have pointed out microcirculation disorders as the main cause of vascular diseases. In this paper, we present an analysis of the existing diagnostic methods and identify the advantages, disadvantages and limitations of each method. The analysis showed that there are no accurate quantitative criteria for assessment and diagnosis of peripheral circulation in any of the methods. Our results can be used for the development of medical and technical requirements for hardware and software systems for quantitative diagnosis of microhemodynamic disorders. (Int J Biomed. 2015;5(4):228-230.)
\end{abstract}

Keywords: microcirculation; vascular diseases; quantitative criteria of diagnosis.

\section{Introduction}

Currently, vascular diseases (chronic venous insufficiency, chronic arteriosclerosis obliterans of the lower extremities, diabetic angiopathy, and others) are the leading cause of disability all over the world, including among people of productive age. Furthermore, there is a tendency to a growth in the number of patients with these types of diseases and a decrease in their average age. Recent publications have pointed out microcirculation disorders as the main cause of vascular pathology [1]. The main problems occurring in the research of such disorders are as follows [2]:

(1) a lack of quantitative criteria and accepted methods of diagnosis, which leads to the detection of the diseases at later stages and late treatment,

(2) the impossibility of developing new methods of treatment and the efficiency investigation without monitoring microcirculation condition.

For these reasons, the choice of a method for quantitative evaluation of microcirculation parameters is the main issue in the diagnosis and treatment of patients with vascular diseases.

\section{Methods}

The main problems in microcirculation research stem from the extremely small size of microvessels and their high branching. Nailfold capillaroscopy, reflecting microvascular function in all parts of the body, has been the main method of microcirculation research so far. There are several main advantages and disadvantages of this method (Table 1) $[3,4]$.

Table 1.

Advantages and disadvantages of capillaroscopy

\begin{tabular}{|c|c|}
\hline Advantages & Disadvantages \\
\hline Simple and non-invasive & Impossible to give \\
\hline Instant visualization & a quantitative characteristics \\
\hline $\begin{array}{l}\text { The possibility of a detailed } \\
\text { evaluation of all parts of the } \\
\text { microvasculature }\end{array}$ & $\begin{array}{l}\text { Results depend on the } \\
\text { experience of the medical } \\
\text { staff }\end{array}$ \\
\hline The availability of biological objects & \\
\hline $\begin{array}{l}\text { A lack of significant anatomical } \\
\text { features in the region of interest }\end{array}$ & \\
\hline
\end{tabular}

Currently, the most routine methods for research of regional blood flow and microcirculation in clinical practice are the following [5-7]: transcutaneous oximetry, laser Doppler flowmetry (LDF), high-frequency Doppler ultrasound, tissue oximetry, radionuclide methods, impedance plethysmography, and photoplethysmography. We made a comparative analysis of these methods. We found that each method has its advantages and limitations, but none of them complies fully with clinicians' requirements. Due to this deficiency, it is recommended to use combined methods for microvasculature assessment [8]. 


\section{Results}

Our analysis of the existing diagnostic methods showed that when used together they give superfluous information about microcirculation parameters (Table 2). Unfortunately, there are no accurate quantitative criteria for assessment and diagnosis of peripheral circulation in any of the methods. Moreover, each technique has its significant disadvantages and limitations. Therefore, the problem of quantitative assessment of peripheral circulation is urgent and promising.
The purposes of the subsequent stages of the study are to:

- develop a structure of a hardware and software system for quantitative diagnosis of microhemodynamics (solution of diagnostic issues), and

- develop software and algorithmic tools for biorelevant therapy based on the received diagnostic data (solution of therapeutic issues).

A simplified scheme of a developed bioengineering system is shown in Fig.1. It reflects therapeutic and diagnostic circuits. Thus, this system corresponds to the purposes of the subsequent stages of study.

Table 2.

Comparative analysis of different methods for diagnosis of peripheral circulation

\begin{tabular}{|c|c|c|c|c|c|c|}
\hline & \multirow{2}{*}{$\begin{array}{c}\text { High-frequency } \\
\text { Doppler ultrasound }\end{array}$} & \multirow[t]{2}{*}{ LDF } & \multirow{2}{*}{$\begin{array}{l}\text { Transcutaneous } \\
\text { oximetry }\end{array}$} & \multirow[t]{2}{*}{ Tissue oximetry } & \multicolumn{2}{|c|}{ Radionuclide methods } \\
\hline & & & & & $\begin{array}{l}\text { Perfusion } \\
\text { scintigraphy }\end{array}$ & Clearance method \\
\hline $\begin{array}{l}\text { Functional } \\
\text { principle }\end{array}$ & \multicolumn{2}{|c|}{ Doppler effect } & $\begin{array}{l}\text { local heating of } \\
\text { tissue }\end{array}$ & $\begin{array}{l}\text { the interaction } \\
\text { of photons with } \\
\text { biological tissue }\end{array}$ & \multicolumn{2}{|c|}{$\begin{array}{c}\text { RFP loading with registration of relevant } \\
\text { parameters }\end{array}$} \\
\hline Probing depth & $3.5 \ldots 8 \mathrm{~mm}$ & $\sim 1 \mathrm{~mm}$ & $\begin{array}{c}\text { surface layer of the } \\
\text { skin }\end{array}$ & $\sim 2 \mathrm{~cm}$ & \multicolumn{2}{|c|}{ skin, muscles } \\
\hline $\begin{array}{l}\text { Registered } \\
\text { parameters }\end{array}$ & $\begin{array}{l}\text { - linear and } \\
\text { volumetric blood } \\
\text { flow velocity; } \\
\text { - rheographic } \\
\text { index }\end{array}$ & $\begin{array}{l}\text { - microcirculation } \\
\text { index; } \\
\text { - mean } \\
\text { perfusion in the } \\
\text { microvasculature; } \\
\text { - average blood } \\
\text { flow modulation; } \\
\text { - coefficient of } \\
\text { variation; } \\
\text { - bypass index; } \\
\text { - spectral } \\
\text { characteristic }\end{array}$ & $\begin{array}{l}\text { - partial pressure } \\
\text { of oxygen in the } \\
\text { surface layers of } \\
\text { the skin }\left(\mathrm{TcpO}_{2}\right)\end{array}$ & $\begin{array}{l}\text {-absorption } \\
\text { coefficient }\left(\mu_{\mathrm{a}}\right) ; \\
\text { - transport scattering } \\
\text { coefficient }\left(\mu_{\mathrm{s}}^{\prime}\right) ; \\
\text { - concentrations of } \\
\text { oxy- deoxy- and total } \\
\text { hemoglobin }\left(\left[\mathrm{HbO}_{2}\right],\right. \\
[\mathrm{HHb}] \text { and }[\mathrm{THb}]) ; \\
\text { - tissue oxygen } \\
\text { saturation }\left(\mathrm{StO}_{2}\right)\end{array}$ & $\begin{array}{l}\text { radiation } \\
\text { intensity of } \\
\text { accumulated } \\
\text { radiopharma- } \\
\text { ceutical }\end{array}$ & $\begin{array}{l}\text { radiopharmaceutical } \\
\text { washout period }\end{array}$ \\
\hline $\begin{array}{l}\text { Using the } \\
\text { functional tests }\end{array}$ & \begin{tabular}{|l|} 
is required for \\
increase the \\
information \\
content of research
\end{tabular} & $\begin{array}{l}\text { is required as one } \\
\text { of the stages of } \\
\text { research }\end{array}$ & $\begin{array}{l}\text { is required for } \\
\text { increase the } \\
\text { information } \\
\text { content of research }\end{array}$ & \begin{tabular}{|l|} 
is required for \\
increase the \\
information content \\
of research
\end{tabular} & not required & $\begin{array}{l}\text { is required for increase } \\
\text { the information content } \\
\text { of research }\end{array}$ \\
\hline $\begin{array}{l}\text { Availability of } \\
\text { quantitative } \\
\text { criteria for } \\
\text { diagnosis }\end{array}$ & - & \pm & \pm & - & - & - \\
\hline \multirow[t]{2}{*}{$\begin{array}{l}\text { Features of the } \\
\text { method }\end{array}$} & \multicolumn{4}{|c|}{$\begin{array}{l}\text { - integrated of estimated parameters; } \\
\text { - a limited number of technical implementations; } \\
\text { - a limited number of measurement techniques }\end{array}$} & \multirow{2}{*}{\multicolumn{2}{|c|}{$\begin{array}{l}\text { - possibility of investigating micro- } \\
\text { circulation in the skin and in muscle; } \\
\text { - possibility of differentiating nutritional } \\
\text { and bypass blood flow. }\end{array}$}} \\
\hline & \begin{tabular}{|l|} 
- audible and visual \\
control of sensor \\
installation; \\
- determine the \\
type of vessel in \\
the form of the \\
curve; \\
- evaluation of the \\
direction of blood \\
flow
\end{tabular} & $\begin{array}{l}\text { - understanding of } \\
\text { the results is more } \\
\text { difficult than the } \\
\text { study itself; } \\
\text { - data obtained } \\
\text { in the foreign } \\
\text { literature can't be } \\
\text { used in Russia }\end{array}$ & \multicolumn{2}{|c|}{\begin{tabular}{|l|l|} 
- some algorithms - insufficient \\
successfully used & information about \\
in clinical practice & the application in \\
& Russia; \\
& - absence of \\
correct algorithms \\
for calculating \\
parameters
\end{tabular}} & & \\
\hline $\begin{array}{c}\text { Examples of } \\
\text { devices }\end{array}$ & \begin{tabular}{|c|} 
Minimax- \\
Doppler-K \\
(Minimax, St. \\
Petersburg)
\end{tabular} & $\begin{array}{l}\text { LAKK-02 } \\
\text { (LAZMA, } \\
\text { Moscow) }\end{array}$ & $\begin{array}{l}\text { TCM400 } \\
\text { (Radiometer, } \\
\text { Denmark) }\end{array}$ & $\begin{array}{c}\text { OxiplexTS (ISS Inc., } \\
\text { USA) }\end{array}$ & $\begin{array}{c}\text { Sigma-410S } \\
\text { (USA, Germany) }\end{array}$ & $\begin{array}{l}\text { DIACAM (Siemens, } \\
\text { Erlangen, Germany) }\end{array}$ \\
\hline
\end{tabular}




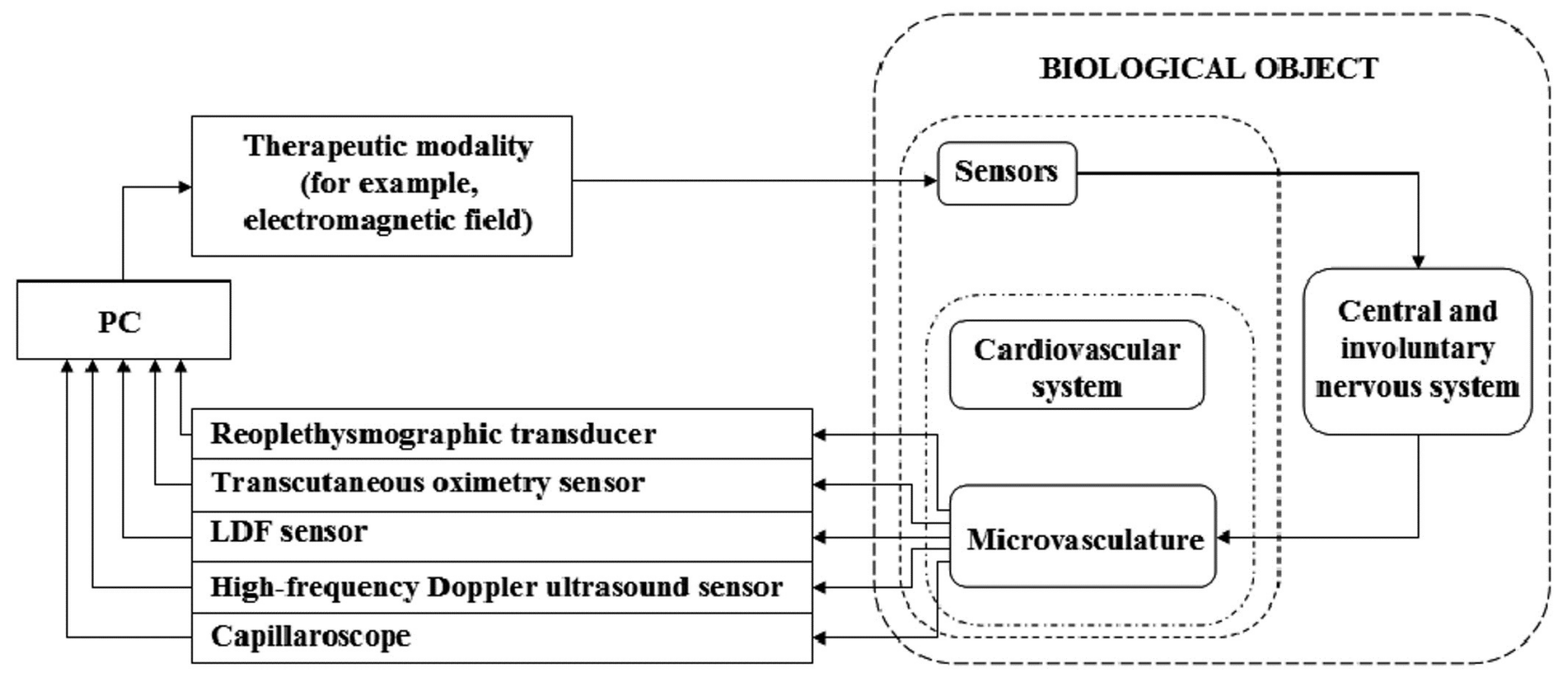

Fig. 1. A simplified scheme of a developed bioengineering system

Our results can be used for the development of medical and technical requirements for hardware and software systems for quantitative diagnosis of microhemodynamic disorders.

\section{Competing interests}

The authors declare that they have no competing interests.

\section{Acknowledgements}

This work was supported in part by RFBR, research project No. 15-08-99682.

\section{References}

1. Koshkin VM, Karalkin AV, Saitova GD, Nastavsheva OD. Micro- and macrocirculation in the lower extremities in patients with various forms of chronic venous insufficiency. Regional Haemodynam Microcircul. 2004; 10: 47-51.

2. Zolotnitskaya VP, Leontieva NV, Talantov SV, Andrushina $\mathrm{NB}$, Sedletskaya EYu. Radionuclide diagnose in the control of the efficiency of laserotherapy in patients with pathology of lower extremities. Regional Haemodynam Microcircul. 2002; 3:28-33.
3. Berezhanski PV, Melnikova IM, Mizernitski YuL. Modern views on the participation of microcirculatory alterations in the pathogenesis of allergic inflammation. Regional Haemodynam Microcircul. 2012;44: 4-11

4. Kulchitskaya D. Laser Doppler flowmetry in assessing the efficiency of physiotherapy effects. Cosmetics \& Medicine. 2009; 2: 22-27

5. Petrishchev NN, Vasin EY. (2009) A method for determining the reactivity and microvascular endothelial vasomotor function using high-frequency Doppler. Retrieved from http://minimax.ru/2011/07/19/sposob-opredeleniyareaktivnosti-sos/

6. Russian consensus "Diagnosis and treatment of patients with critical limb ischemia." Retrieved from http:// diabeticfoot.ru/d/176414/d/rossiyskiy_konsensus.pdf

7. Luzhnov PV, Shamaev DM, Iomdina EN, Tarutta EP, Markosyan GA, Shamkina LA, Sianosyan AA. Transpalpebral tetrapolar reoophtalmography in the assessment of parameters of the eye blood circulatory system. Vestn Ross Akad Med Nauk. 2015;70 (3): 372-7 [Article in Russian].

8. Azizov GA. Estimation of the microcirculation disorders' rate in vascular diseases of the lower extremities using the functional tests. Regional Haemodynam Microcircul. 2006;17: 37 